\title{
PRNP variation in UK sporadic and variant Creutzfeldt Jakob disease highlights genetic risk factors and a novel non-synonymous polymorphism

\author{
Matthew T Bishop*, Catherine Pennington, Craig A Heath, Robert G Will and \\ Richard SG Knight
}

Address: National CJD Surveillance Unit, University of Edinburgh, Bryan Matthews Building, Western General Hospital, Crewe Road, Edinburgh, EH4 2XU, UK

Email: Matthew T Bishop* - m.bishop@ed.ac.uk; Catherine Pennington - catherine.pennington@ed.ac.uk; Craig A Heath - craigheath@nhs.net; Robert G Will -r.g.will@ed.ac.uk; Richard SG Knight -r.knight@ed.ac.uk

* Corresponding author

Published: 26 December 2009

BMC Medical Genetics 2009, 10:146 doi:10.1 I86/147/-2350-10-146
Received: 27 April 2009

Accepted: 26 December 2009

This article is available from: http://www.biomedcentral.com/I47I-2350/I0//46

(C) 2009 Bishop et al; licensee BioMed Central Ltd.

This is an Open Access article distributed under the terms of the Creative Commons Attribution License (http://creativecommons.org/licenses/by/2.0), which permits unrestricted use, distribution, and reproduction in any medium, provided the original work is properly cited.

\begin{abstract}
Background: Genetic analysis of the human prion protein gene (PRNP) in suspect cases of Creutzfeldt-Jakob disease (CJD) is necessary for accurate diagnosis and case classification. Previous publications on the genetic variation at the PRNP locus have highlighted the presence of numerous polymorphisms, in addition to the well recognised one at codon 129 , with significant variability between geographically distinct populations. It is therefore of interest to consider their influence on susceptibility or the clinico-pathological disease phenotype. This study aimed to characterise the frequency and effect of PRNP open reading frame polymorphisms other than codon 129 in both disease and control samples sourced from the United Kingdom population.
\end{abstract}

Methods: DNA was extracted from blood samples and genetic data obtained by full sequence analysis of the prion protein gene or by restriction fragment length polymorphism analysis using restriction enzymes specific to the gene polymorphism under investigation.

Results: 147 of 166 confirmed cases of variant CJD (vCJD) in the UK have had PRNP codon 129 genotyping and all are methionine homozygous at codon I29; I I8 have had full PRNP gene sequencing. Of the latter, 5 cases have shown other polymorphic loci: at codon $219(2,1.69 \%)$, at codon $202(2,1.69 \%)$, and a 24 bp deletion in the octapeptide repeat region (I, 0.85\%). E2 I9K and D202D were not found in sporadic CJD (sCJD) cases and therefore may represent genetic risk factors for VCJD.

Genetic analysis of 309 confirmed UK sCJD patients showed codon 129 genotype frequencies of MM: 59.5\% ( $n$ $=184)$, MV: $21.4 \%(n=66)$, and VV: 19.1\% $(n=59)$. Thirteen $(4.2 \%)$ had the AI I7A polymorphism, one of which also had the P68P polymorphism, four (1.3\%) had a 24 bp deletion, and a single patient had a novel missense variation at codon 167. As the phenotype of this latter case is similar to $s C J D$ and in the absence of a family history of CJD, it is unknown whether this is a form of genetic CJD, or simply a neutral polymorphism.

Conclusions: This analysis of PRNP genetic variation in UK CJD patients is the first to show a comprehensive comparison with healthy individuals $(n=970)$ from the same population, who were genotyped for the three most common variations (codon 129, codon 117, and 24 bp deletion). These latter two genetic variations were equally frequent in UK SCJD or VCJD cases and a normal (healthy blood donor) UK population. 


\section{Background}

At the time of this study, there were 166 confirmed cases of vCJD in the UK, and a further 44 patients in other countries. (For current UK and worldwide figures see http:// www.cjd.ed.ac.uk) The widely accepted hypothesis is that vCJD was initially acquired through dietary infection with bovine produce contaminated with the infectious agent of bovine spongiform encephalopathy (BSE) [1,2]. Additionally, secondary cases have resulted from blood transfusion [3,4]. The proposed agent (designated a 'prion') has not been fully characterised but disease and infectivity are generally associated with an abnormally folded form (designated $\mathrm{PrPSc}$ ) of the host encoded prion protein $(\mathrm{PrPC})[5]$. Variant CJD shows marked differences in clinical presentation [6] and neuropathology [7] when compared with sporadic CJD (sCJD) which has a worldwide distribution affecting approximately 1-2 cases per million population per year and has an unknown aetiology. In comparison to sCJD, vCJD typically occurs in younger individuals (median ages of onset: 66 \& 26 years respectively) and with a longer disease duration (median durations: 4 and 14 months respectively). There are two other forms of CJD: genetic and iatrogenic. Genetic CJD (gCJD) is an autosomal dominant inherited illness related to underlying mutations of the prion protein gene (PRNP). There are other genetic human prion diseases (Fatal Familial Insomnia (FFI), and Gerstmann Sträussler Scheinker syndrome (GSS)) traditionally separated from gCJD on clinico-pathological grounds, but which are related by certain common core features and an underlying causal PRNP mutation. Iatrogenic CJD (iCJD) results from the accidental person-to-person (medical or surgical) transmission of other forms of CJD.

Genetic analysis of the sCJD and vCJD disease cohort has an important role in accurate diagnostic classification, especially as genetic prion disease cannot always be differentiated clinically from other forms of prion disease and a family history is absent in up to about $50 \%$ of cases [8]. The gene coding for prion protein, PRNP, is a key target for analysis. This gene is highly conserved between mammalian species indicating an important biological role for the prion protein, but PRNP shows significant variation at the individual level in humans [9]. Over twenty missense and nonsense mutations have been identified in the open reading frame (ORF) that have been linked to genetic prion disease phenotypes [10]. Other polymorphic sites in PRNP (over twenty examples) that are not directly linked to a disease phenotype have been identified through analysis of suspected CJD cases and other populations. These polymorphisms may have disease modulating capacities and these effects may vary according to the population under investigation. The conversion of $\mathrm{PrPC}^{\mathrm{C}}$ to $\mathrm{PrPSc}^{\mathrm{S}}$ is thought to involve some form of oligomerisation and the melting and refolding of the peptide chains. It is therefore possible that any changes to the amino-acid sequence could alter the thermodynamic stability of the protein and affect the kinetics of structural conversions [11].

The PRNP polymorphic residue at codon 129 (ATGmethionine to GTG-valine, M129V) has been studied extensively. Variation in the genotype frequencies occurs according to geographical region. In most countries studied, the MM and MV frequencies are approximately 40$50 \%$ however there is a large difference seen in Japan where the normal population frequencies are: MM 92\%, MV 8\%, and VV 0\% [12]. Genotype data from other countries suggest a gradual increase in MM genotype frequency from West to East which may reflect the historical human migrations [12]. It has been shown that M129V may affect susceptibility to prion diseases [13], the incubation period in acquired forms [14,15] and the clinico-pathological phenotype [16]. Codon 129 homozygosity is considered a risk factor for human prion disease: while $~ 40 \%$ of the normal population is MM, $\sim 70 \%$ of sCJD patients, and all clinical vCJD patients tested to date have this genotype [17]. Homozygosity has also been shown to be a risk factor, and reduces the incubation time, for both human growth hormone associated iCJD [14] and kuru [15] (an historical disease of the Fore linguistic tribe of Papua New Guinea transmitted by endocannibalism). In some circumstances, the genotype at codon 129 can determine the disease phenotype for human genetic prion cases associated with pathogenic mutations [16]. In addition, variation in sCJD clinico-pathological phenotype can be associated with specific genotypes [18].

The most significant finding with respect to codon 129 genotype and CJD is that all clinically probable and neuropathologically confirmed cases of vCJD so far analysed world-wide ( $\mathrm{n}=147 \mathrm{UK}$ and 44 non-UK) have the MM genotype and, therefore, this genotype is categorised as a risk factor. However, there is evidence that other 129 genotypes are susceptible to BSE/vCJD infection and that they may develop disease after a longer incubation period than in $\mathrm{MM}$ individuals. It is hypothesised that $\mathrm{MV}$ and $\mathrm{VV}$ cases will occur in the future [19]. There are four reports of transmission of vCJD infection via blood transfusion from blood donors who later developed vCJD [3,4,20,21]. In three instances, the recipients developed clinical vCJD and all three were homozygous MM at codon 129. In the fourth case, there was no clinical or neuropathological evidence of $\mathrm{VCJD}$ in the recipient, but disease-related abnormal prion protein was found in the spleen and a lymph node. This individual was MV at codon 129 and may represent subclinical infection in a non-MM individual; it is impossible to know whether the individual would have developed clinical vCJD if they had lived longer [21]. In addition, two of three samples in an anon- 
ymous appendix study in the UK that were positive for deposition of prion disease associated PrPsc were genotyped as VV [22].

Variation in the DNA sequence of PRNP may be linked to other genetic changes separate to the prion protein itself, such as promoter elements or regions more distant to the PRNP gene. To understand more fully the control mechanisms of PRNP gene expression, such as promoter activity, extensive studies have been undertaken to examine the region of chromosome 20 adjacent to the PRNP locus [2326]. Analysis of a $4.8 \mathrm{~kb}$ region around $P R N P$, identified 3 polymorphisms in areas that were predicted to control gene expression [24].

This study involved the genetic analysis of CJD cases referred to the National CJD Surveillance Unit during routine UK surveillance and a specific project to determine normal population PRNP polymorphisms in the United Kingdom.

\section{Methods}

\section{Control DNA Samples}

The Scottish Blood Donor controls $(\mathrm{n}=778)$ were supplied as $0.5 \mathrm{ml}$ aliquots of frozen whole blood by Dr Ian MacGregor (National Science Laboratory, Scottish National Blood Transfusion Service) from samples taken as part of a human prion disease study of blood markers (covered by Multi-Centre Research Ethics Committee for Scotland approval, reference MREC/02/10/46). There was no ethical approval for full PRNP sequence analysis of these samples.

DNA samples (UK DNA controls, $\mathrm{n}=192$ ) were purchased from the European Collection of Cell Cultures (ECACC) originating from donors in the UK cities of Oxford and Birmingham. (Catalogue references: HRC-1 and HRC-2.)

For the normal population data, the Scottish Blood Donor and UK DNA controls were genotyped for polymorphisms at M129V, and A117A, and the 24 bp deletion in the $\mathrm{N}$-terminus octapeptide repeat region (the three most common polymorphic loci of PRNP). For the CJD cases, we had PRNP sequence analysis data on 118 vCJD and 309 sCJD patients.

\section{Patient Samples}

Patient blood samples were taken from individuals under clinical review for suspected CJD, by venipuncture, into citrate anticoagulant treated blood collection tubes. Once received into the laboratory the blood was separated into its major constituents as follows:
1. Whole blood was spun at $450 \mathrm{~g}$ for 10 minutes to separate platelet rich plasma, buffy coat, and red blood cells (RBC).

2. Platelets were removed from the plasma by two washes in phosphate buffered saline (PBS) with centrifugations at $16,000 \mathrm{~g}$ leaving platelet poor plasma. This was stored at $-80^{\circ} \mathrm{C}$.

3. The buffy coat fraction was cleared of contaminating platelets by centrifugation at $180 \mathrm{~g}$ for 10 minutes, then the RBC were removed by lysis with distilled water and centrifugation at $180 \mathrm{~g}$ for 10 minutes. Finally the buffy coat fraction was washed in PBS then centrifuged at $100 \mathrm{~g}$ for 10 minutes before storing at $80^{\circ} \mathrm{C}$.

4. The RBC were washed twice with PBS, with centrifugation at $180 \mathrm{~g}$ for 10 minutes each time. RBC were stored at $-80^{\circ} \mathrm{C}$ as a $50 \%$ solution in PBS.

\section{DNA Extraction}

DNA from cases and controls was prepared from $200 \mu \mathrm{l}$ of frozen whole blood by cell lysis and column purification using the DNA Blood Mini Kit (Qiagen, UK) and stored at $-20^{\circ} \mathrm{C}$.

\section{PCR-RFLP Analysis}

Amplification of the PRNP gene sequence (NCBI Accession: AL133396) by the polymerase chain reaction (PCR) involved forward primer (5'-TGA TAC CAT TGC TAT GCA CTC ATT C-3') and reverse primer (5'-GAC ACC ACC ACT AAA AGG GCT GCA G-3') at 5 pmoles each per reaction (Eurofins MWG Operon, Germany), that are specific for a 956 bp sequence. Each reaction contained $2 \mathrm{mM} \mathrm{MgCl}$ (Qiagen, UK), $0.2 \mathrm{mM}$ dNTPs (Promega, UK), and 1 Unit of Taq Polymerase (HotStarTaq, Qiagen, UK). The thermal cycling program included an annealing temperature step-down from $65^{\circ} \mathrm{C}$ to $60^{\circ} \mathrm{C}$ over ten cycles followed by 30 cycles at $60^{\circ} \mathrm{C}$.

Confirmation of the codon 129 genotype was performed by restriction enzyme digestion at $37^{\circ} \mathrm{C}$ with NspI (New England Biolabs, UK). This enzyme cleaves the amplicon at PRNP codon 155 and at codon 129 only when the latter sequence codes for valine (-GTG-). This allowed for discrimination of the three genotypes: $\mathrm{MM}, \mathrm{MV}$, and $\mathrm{VV}$ by agarose gel electrophoresis and ethidium bromide staining, Figure 1. The presence of a $24 \mathrm{bp}$ deletion in the octapeptide repeat region could be observed from the codon 129 genotyping agarose gel data due to an additional band shift for the restriction enzyme digest products. Codon 117 polymorphism genotype was determined by restriction enzyme digestion of the same PRNP PCR product with PvuII (New England Biolabs, 
A: Polymorphism M129V

Mw MV MM VV

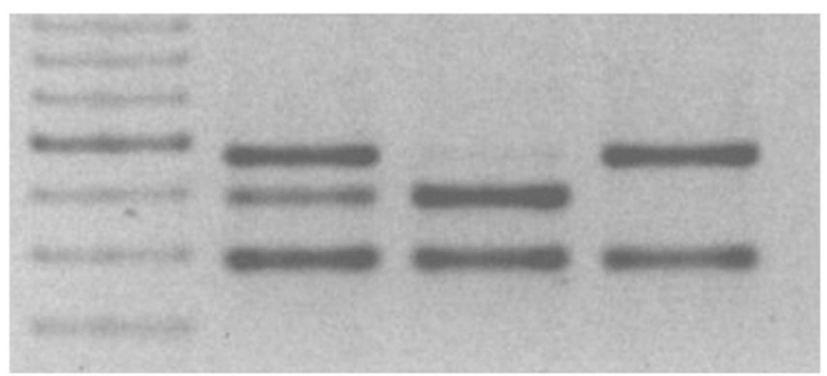

\section{C: Polymorphism D167G}

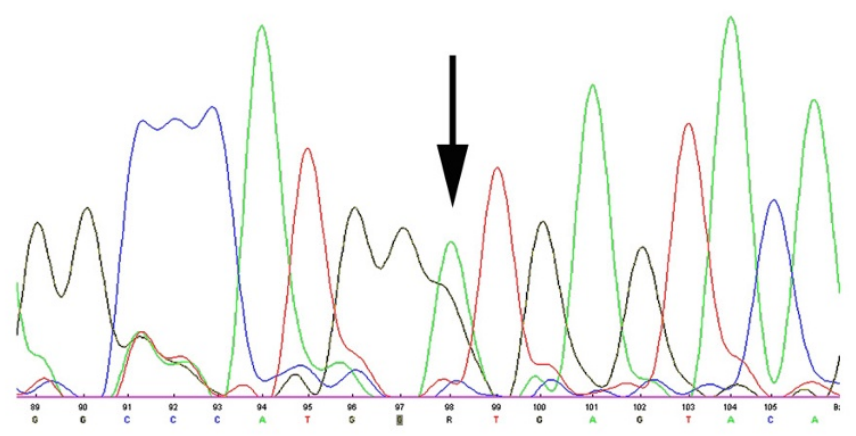

D: Polymorphism D202D

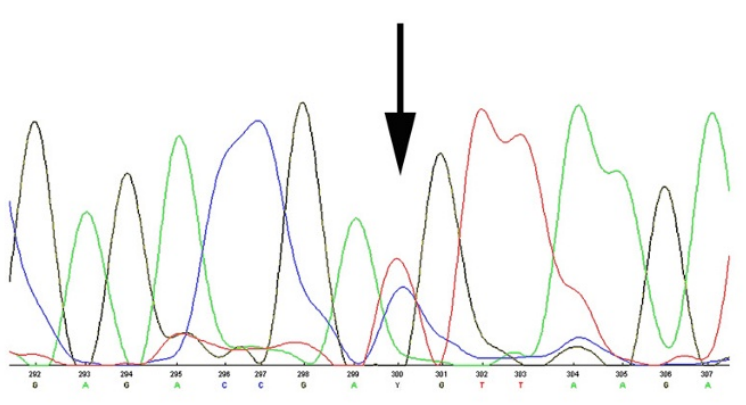

\section{E: Polymorphism E219K}

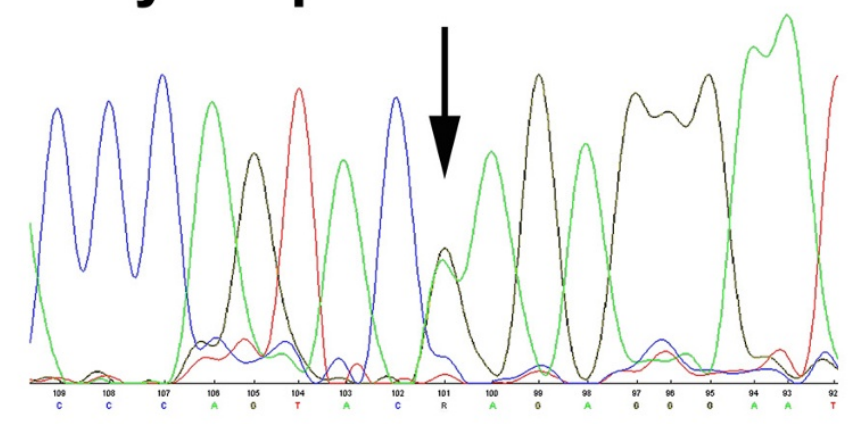

\section{Figure I}

Detection of PRNP polymorphisms. Panels A and B: Genotyping by PCR amplification of PRNP and restriction enzyme digest. (Mw: 100 bp molecular weight ladder (dark band 600 bp); MV, MM, VV: codon 129 genotypes; WT: wild-type codon I 17 genotype; MUT: heterozygous for codon I 17 polymorphism) Panels C, D, and E: Electropherograms for polymorphisms detected by sequence analysis. (Arrows point to heterozygous base position.)

UK) at $37^{\circ} \mathrm{C}$. This enzyme cleaves the wild-type PCR product and not the codon 117 variant. In samples heterozygous for the codon 117 polymorphism this enzyme produces digest products of sizes 499 and 457 in addition to the full length $956 \mathrm{bp}$ PCR amplicon. (Figure 1)

\section{Sequencing}

If consent from the patient, or relative, had been obtained for full genetic analysis then the PCR product was sequenced by fluorescent dye-primer chemistry (Thermo Sequenase Primer Cycle Sequencing Kit, Amersham Biosciences, UK) using an ALF-Express DNA Sequencer (Amersham Biosciences, UK). PCR products were purified 
using a QIAquick PCR Purification Kit (Qiagen, UK) to remove excess primers and other PCR reagents. Four Cy5 labelled sequencing primers were used to give at least 2fold coverage of the entire ORF (5'-AGG TGG CAC CCA CAG TCA GT-3'; 5'-CTA TGC ACT CAT TCA TTA TG-3'; 5'CCT CAA GCT GGA AAA AGA TTA G-3'; 5'-CGA TAG TAA CGG TCC TCA TA-3'). Sequencing reaction products were electrophoresed through ReproGel Long Read acrylamide gels (Amersham Biosciences, UK). ALFwin Software (Amersham Biosciences, UK) was used to align the sequence data with a reference sequence and each codon of the ORF was visually checked by two individuals. This method allows for identification of novel polymorphisms rather than only checking for known ORF sequence changes. (Figure 1)

\section{Statistical Analysis}

Analysis was undertaken through the use of R (v2.9.1) (R Development Core Team (2009). R: A language and environment for statistical computing. R Foundation for Statistical Computing, Vienna, Austria. ISBN 3-900051-07-0. URL: http://www.R-project.org).

\section{Results}

\section{Variant CJD PRNP Sequence Data}

Table 1 shows the results of PRNP gene sequence analysis in $\mathrm{VCJD}$ cases where material and specific consent was available. 147 confirmed cases were genotyped at codon 129 and all were methionine homozygotes (MM). Complete sequence analysis of the PRNP ORF was performed for 118 cases and found five individuals with genetic variation. Two had a synonymous (silent) polymorphism at codon 202 (GAC-aspartic acid to GAT-aspartic acid; D202D), two had a non-synonymous change at codon 219 (GAG-glutamic acid to AAG-lysine; E219K), and one had a 24 bp deletion (classified as DelR34 according to [27]). The DelR34 and the two D202D patients fulfilled the diagnostic criteria [28] for definite vCJD. The two patients with E219K genotype did not have a post mortem and were classified as probable vCJD. The E219K mutation has not been seen in white Caucasian populations and has so far only been detected in populations from Asian and the Pacific [29]. The two individuals with the E219K genotype found in this study were not of white Caucasian origin (the specific ancestral origin is unknown).

\section{Sporadic CJD Sequence Data}

Sequence variation for 309 confirmed sCJD patients is shown in Table 2. Codon 129 genotyping produced allele frequencies similar to that expected for this disease from other studies $[13,18]$ and to the overall figures published by the UK National CJD Surveillance Unit (MM 63\%, MV 19\%, VV 18\%; n = 647) (http://www.cjd.ed.ac.uk; Annual Report 2008). Complete sequence analysis on these patients found thirteen with the silent polymorphism at codon 117 (GCA-alanine to GCG-alanine; A117A), which included one individual with an additional silent polymorphism at codon 68 (P68P), and four cases with a 24 bp deletion in the octapeptide repeat region. Of these 17 patients 13 were classified as definite and four as probable sCJD according to the diagnostic criteria. In addition, one patient was found to have a non-synonymous polymorphism at codon 167 (GAT-aspartic acid to GGT-glycine; $\mathrm{D} 167 \mathrm{G})$. There was nothing in the clinical phenotype suggesting that this could be a causative mutation of gCJD and the patient was classified as probable "sporadic CJD". Neuropathological analysis confirmed sporadic CJD with type 1 prion protein isoform present, and genetic analysis showed methionine homozygosity at codon 129 of PRNP.

\section{Control Codon I29 Genotype Data}

Codon 129 genotype frequencies are given in Table 2 for samples from the UK DNA and Scottish Blood Donor

Table I: PRNP gene sequence variation in vCJD cases

\begin{tabular}{lll}
\hline Codon & Number Tested & Genotype Data \\
\hline 129 (Met/Val) & 147 & All cases MM \\
\cline { 2 - 3 } & 4 (blood transfusion associated infections) & MM $(\mathrm{n}=3)$ \\
\cline { 2 - 3 } & 2 (appendix tissue) & $\mathrm{n}=1)^{*}$ \\
\hline 202 (Asp/Asp) & 118 & VV $(\mathrm{n}=2)^{* *}$ \\
\hline 219 (Glu/Lys) & 118 & DD $(\mathrm{n}=2)$ \\
\hline 24 bp deletion & 118 & EK $(\mathrm{n}=2)$ \\
\hline
\end{tabular}

* Non-clinical, non-neuropathologically confirmed case

** From anonymous screening program for $\mathrm{vCJD}$ associated PrPSc deposition 
Table 2: PRNP gene sequence variation in SCJD cases and controls

\begin{tabular}{|c|c|c|c|}
\hline PRNP Variation & 309 sCJD Patients & I 92 UK DNA Controls & 778 Scottish Blood Donor Controls \\
\hline Codon 129 (Met/Val) & $\begin{array}{l}M M(n=184 ; 59.5 \%) \\
M V(n=66 ; 21.4 \%) \\
\operatorname{VV}(n=59 ; 19.1 \%)\end{array}$ & $\begin{array}{l}M M(n=90 ; 46.9 \%) \\
M V(n=87 ; 45.3 \%) \\
V V(n=15 ; 7.8 \%)\end{array}$ & $\begin{array}{l}M M(n=337 ; 43.3 \%) \\
M V(n=344 ; 44.2 \%) \\
V V(n=97 ; 12.5 \%)\end{array}$ \\
\hline Codon 117 (Ala/Ala) & $\begin{array}{l}\mathrm{n}=13 ; 4.2 \% \\
(10.4 \% \text { of } \mathrm{MV} / \mathrm{VV} \text { cases })\end{array}$ & $\begin{array}{l}\mathrm{n}=9 ; 4.7 \% \\
(\mathrm{I} 0.3 \% \text { of } \mathrm{MV} / \mathrm{VV} \text { cases })\end{array}$ & $\begin{array}{l}n=47 ; 6.0 \% \\
(10.7 \% \text { of } M V / V V \text { cases })\end{array}$ \\
\hline 24 bp Deletion & $\begin{array}{l}\mathrm{n}=4 ; \mathrm{I} .3 \% \\
\text { Deletion Class } \\
\text { R34 }(\mathrm{n}=3) \\
\text { R3 }(\mathrm{n}=1)\end{array}$ & $\begin{array}{l}\mathrm{n}=\mathrm{I} ; 0.5 \% \\
\text { Deletion Class } \\
\text { R2 }(\mathrm{n}=\mathrm{I})\end{array}$ & $\begin{array}{l}\mathrm{n}=12 ; 1.5 \% \\
\text { Deletion Class } \\
\text { R34 }(\mathrm{n}=12)\end{array}$ \\
\hline $\begin{array}{l}\text { Codon } 167 \\
\text { (Asp/Gly) }\end{array}$ & $D G(n=1 ; 0.32 \%)$ & (no sequence data available) & (no sequence data available) \\
\hline $\begin{array}{l}\text { Codon } \\
68 \\
\text { (Pro/Pro) }\end{array}$ & $\mathrm{PP}(\mathrm{n}=1 ; 0.32 \%)$ & (no sequence data available) & (no sequence data available) \\
\hline
\end{tabular}

controls. Together with the published Edinburgh/Belfast blood donors, the figures are similar across the three groups and combined ( $\mathrm{n}=1158$ ) give the predicted UK national genotype frequencies of $44.1 \%$ (MM), $44.5 \%$ $(\mathrm{MV})$, and $11.4 \%(\mathrm{VV})$. As there is a significant difference in age at onset between vCJD and SCJD, and that gender may influence sCJD survival [30], the Scottish Blood Donor data was stratified into four groups according to age (17-30, 31-40, 41-50, and 51-69), Figure 2, and by sex, Figure 3. Statistical analysis (Chi-Squared test) indicated that there were no age $(\mathrm{p}=0.5774,0.1270$, and $0.4781)$ or gender $(p=0.2228,0.9884$, and 0.7527$)$ effects determined by genotype at codon 129 , or 117 , or by the presence of a 24 bp deletion, respectively.

\section{Statistical Comparison (Chi Squared Testing) of Control and Case Data}

Comparisons made between codon 129 genotype frequencies for sCJD, vCJD, and the two control groups showed statistically significant differences $(P<0.001$, Table 3). There was no significant difference in genotype between the two control groups. There was no selection bias for the sequenced SCJD patients as there was no significant difference between that group and the larger group of UK National CJD Surveillance Unit sCJD patients that have been genotyped.

The frequencies of A117A and 24 bp deletion were not statistically different from the control data.
Analysis of the genotype frequencies of D202D and E219K could not be done as they were only found in vCJD and not in the controls, as the latter were not sequenced.

\section{Discussion}

Analysis of PRNP in sCJD, vCJD and controls has highlighted the clear primary role in disease susceptibility for the codon 129 genotype and has provided a base-line for the healthy population for future vCJD susceptibility predictions. In addition, the presence of genetic variation (D202D and E219K) in vCJD that is not seen in sCJD suggests possible additional risk factors. A novel non-synonymous polymorphism (D167G) in a case of suspected sCJD has also underlined the need for PRNP genetic screening of patients.

For accurate diagnosis of the various forms of human CJD, and especially to identify inherited genetic forms, DNA sequence analysis of the PRNP open reading frame (ORF) is necessary. Aside from the detection of any pathogenic mutations, this provides data on any polymorphic residues present, important for full characterisation of nongenetic cases [18]. The majority of non-pathogenic polymorphisms are rare.

Codon 129 genotype frequency data show the clear difference between CJD cases and controls with a reduction in the frequency of $\mathrm{MV}(21.4 \%)$ for sCJD cases compared to the controls ( $\sim 45 \%)$, and $100 \%$ MM cases in vCJD. As the control genotype frequencies were not found to vary by age the case data is unlikely to be due to the significant difference in average age at onset between vCJD and sCJD. If 


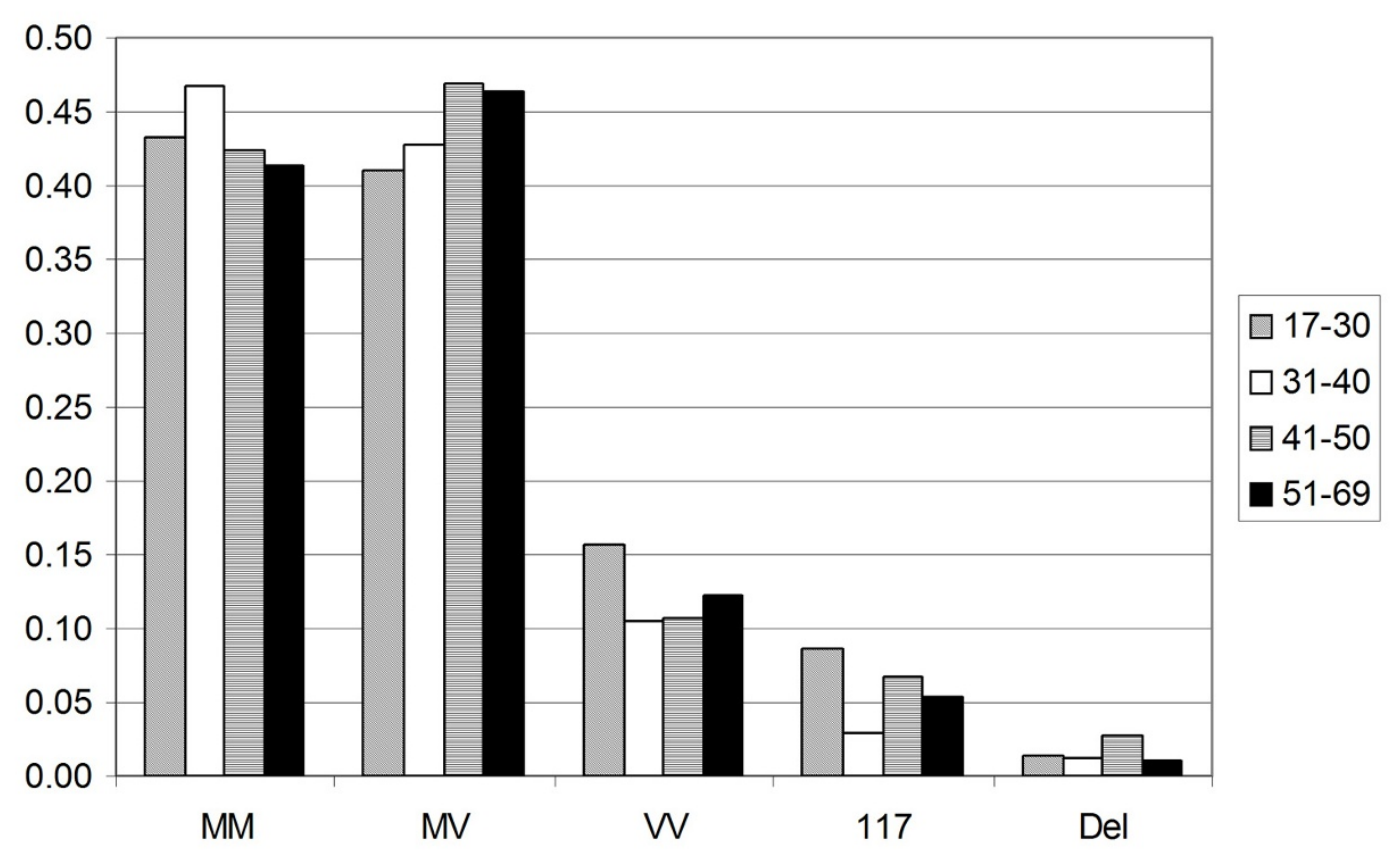

Figure 2

PRNP polymorphisms in Scottish Blood Donors. Codon 129 and PRNP polymorphism frequency in relation to age of Scottish Blood Donors $(n=778)$.

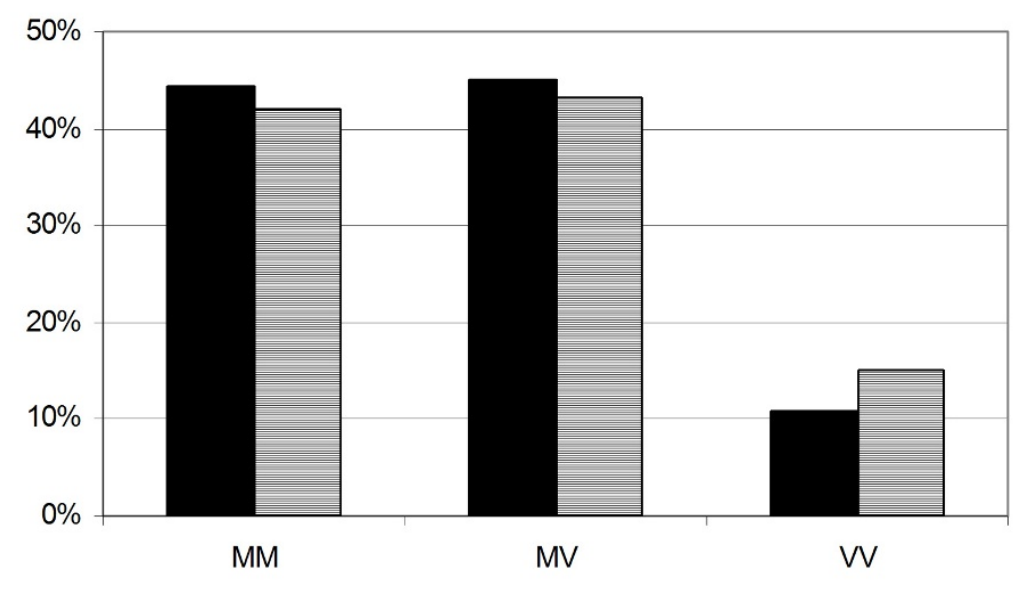

Figure 3

Codon 129 and sex of Scottish Blood Donors. Codon 129 genotype frequency in relation to sex of Scottish Blood Donors $(n=778$, male $=456$ (solid bars), female $=322$ (hatched bars) $)$. 
Table 3: Statistical analysis of PRNP polymorphism frequencies

\begin{tabular}{llll}
\hline & & Chi-Squared Test - P value \\
\hline Comparison & Codon I 29 & Codon II7 & 24 bp Deletion \\
\hline $\begin{array}{l}\text { Sequenced sCJD }(n=309) \text { vs. } \\
\text { All NCJDSU sCJD cases }(n=647)\end{array}$ & 0.582 & NA & NA \\
\hline $\begin{array}{l}\text { UK DNA Controls }(n=192) \text { vs. } \\
\text { Scottish Blood Donors }(n=778)\end{array}$ & 0.185 & 0.584 & $0.452^{*}$ \\
\hline $\begin{array}{l}\text { Sequenced sCjD }(n=309) \text { vs. } \\
\text { UK DNA Controls }(n=192)\end{array}$ & $<0.001$ & 0.975 & $0.700^{*}$ \\
\hline $\begin{array}{l}\text { Sequenced sCJD }(n=309) \text { vs. } \\
\text { Scottish Blood Donors }(n=778)\end{array}$ & & 0.295 & $0.978^{*}$ \\
\hline $\begin{array}{l}\text { Sequenced vCJD }(n=118) \text { vs. } \\
\text { Scottish Blood Donors }(n=778)\end{array}$ & $<0.001$ & NA & $\left.0.86\right|^{*}$ \\
\hline
\end{tabular}

*: Chi-Squared approximation may be incorrect due to low numbers; NA: no comparison could be made

clinical vCJD continues to manifest only in MM genotype individuals then the mathematical models for predicting the total epidemic size can use the population $\mathrm{MM}$ frequency of $44.1 \%$ in the UK population, generated by this study.

Other than M129V the two most common PRNP variants in Caucasian populations are: A117A (frequency 5\%), and a 24 bp deletion in the repeat expansion region ( $1 \%$ ). Full PRNP sequencing of 118 confirmed UK vCJD patients found five with PRNP polymorphisms: two with E219K, two with D202D, and one with a 24 bp deletion (DelR34). The codon 117 polymorphism has not been found, as this is linked to the valine allele at codon 129, and all vCJD cases to date have been 129-MM.

D202D is a synonymous polymorphism and therefore there is no resulting change in prion protein amino acid sequence. No data are available on normal population frequency and the only record of its appearance has been in single French cases of SCJD and iCJD related to human Growth Hormone treatment (Dr N Delasnerie-Laupretre personal communication). There are no structural changes to the prion protein itself and so this DNA sequence alteration would not directly affect protein folding kinetics in a potentially disease causing manner. Missense DNA sequence change GAC (glutamic acid) to AAC (asparagine) at this codon (D202N) is associated with a disease phenotype of Gerstmann-Sträussler-Scheinker syndrome (GSS) a genetic form of human prion disease [31]. The D202D change may be linked with a haplotype, as yet undefined, that alters susceptibility via an alternative route such as differential expression of PrP. This may possibly be the reason why $2 \%$ of tested vCJD cases have been found with this polymorphism. Until control population frequencies are available this possibility remains hypothetical.

E219K is a non-synonymous, missense mutation with a change in amino acid and, therefore, the possibility of protein structural differences which may be linked to an increase in disease susceptibility. This polymorphism has not been found in Western European populations and has only been investigated in detail, with regards to CJD, in Japan [32] and Korea [33] where approximately 12\% and $8 \%$ respectively of the population carry the lysine $(\mathrm{K})$ allele. These studies indicated that E219K influenced the clinical phenotype of GSS in cases with the P102L mutation [34], and found it was a protective factor to SCJD as no confirmed cases of sCJD in Japan or Korea carry the polymorphism. In the two vCJD cases found in our study with E219K, there were no clinico-pathological differences from the other vCJD cases. These patients were of non-Caucasian origin, therefore their genetic ancestry may originate from populations where E219K is more common than the UK [29]. There remains a possibility that the presence of this polymorphism may increase susceptibility to vCJD. A transgenic mouse model suggests that the lysine $(\mathrm{K})$ allele $\operatorname{PrPC}^{\mathrm{C}}$ is more susceptible than the glutamic acid (E) allele to conversion to $\mathrm{PrPSc}^{\text {[35]. }}$

24 bp deletions were found in healthy individuals, SCJD, and vCJD patients at similar frequencies. It is therefore proposed that this genetic variation does not influence the disease state or susceptibility, even though the $\operatorname{PrPC}^{\mathrm{C}}$ formed is significantly different at the metal binding 
domain of the N-terminus, as shown by other studies $[36,37]$. Deletion of two 24 bp repeats in this region has been linked to a familial form of CJD [38].

There have been no reported instances of the D167G sCJD polymorphism associated with familial human prion disease. Evidence for this event to be the cause of a genetic form of CJD in this patient is twofold:

1. The replacement of a large hydrophilic amino acid for a small hydrophobic one may disturb the physical properties of the prion protein and thus accelerate formation of the disease associated form $\left(\mathrm{PrPsc}^{\mathrm{S}}\right)$.

2. Transgenic mouse studies propose that codon 167 may be in a region of the prion protein structure where chaperone molecules bind and accelerate disease transmission [39].

Without the additional evidence of further affected members of the family with the mutation or data on a healthy control population there is no direct proof of the association of D167G and CJD.

\section{Conclusions}

This study has produced genotype frequencies for the most common PRNP genetic variants in the largest cohort of healthy individuals from the UK so far published, and in groups of patients with vCJD and sCJD. These data can act as a benchmark for studying the genotype frequency variation found in human prion disease in the UK. DNA sequence analysis of vCJD patients has revealed the extent of genetic variation within this population to include potential new risk factors, and sCJD analysis has uncovered a novel PRNP polymorphism.

\section{Competing interests}

The authors declare that they have no competing interests.

\section{Authors' contributions}

MTB, RGW, RSGK designed the study. MTB performed the genotyping. CP and CAH assessed the clinical presentation of vCJD and sCJD patients with PRNP polymorphisms. All authors helped draft and approve the final manuscript.

\section{Acknowledgements}

We wish to acknowledge the assistance of Jan Mackenzie (CJD Database), Pascual Sanchez-Juan (statistics), Kelly Ryan (laboratory analysis), and Yvette McCord (laboratory analysis).

This study would not be possible without the continued support of the families of those affected by CJD, and the neurologists and neuropathologists throughout the UK that assist in CJD surveillance.
This project was funded with money from the NEUROCJD grant (DG Research, EC: QLK2 200I 02248 "CJD: epidemiology, risk factors, diagnostic tests and genetics").

\section{References}

I. Bruce ME, Will RG, Ironside JW, McConnell I, Drummond D, Suttie A, McCardle L, Chree A, Hope J, Birkett C, Cousens S, Fraser H, Bostock CJ: Transmissions to mice indicate that 'new variant' CJD is caused by the BSE agent. Nature 1997, 389:498-50I.

2. Will RG, Ironside JW, Zeidler M, Cousens SN, Estibeiro K, Alperovitch A, Poser S, Pocchiari M, Hofman A, Smith PG: A new variant of Creutzfeldt-Jakob disease in the UK. Lancet 1996, 347:921-925.

3. Wroe SJ, Pal S, Siddique D, Hyare H, Macfarlane R, Joiner S, Linehan JM, Brandner S, Wadsworth JD, Hewitt P, Collinge J: Clinical presentation and pre-mortem diagnosis of variant CreutzfeldtJakob disease associated with blood transfusion: a case report. Lancet 2006, 368:2061-2067.

4. Hewitt PE, Llewelyn CA, Mackenzie J, Will RG: Creutzfeldt-Jakob disease and blood transfusion: results of the UK Transfusion Medicine Epidemiological Review study. Vox Sang 2006, 9I:22I-230.

5. Prusiner SB: Novel proteinaceous infectious particles cause scrapie. Science 1982, 216:136-144.

6. Will RG, Zeidler M, Stewart GE, Macleod MA, Ironside JW, Cousens SN, Mackenzie J, Estibeiro K, Green AJ, Knight RS: Diagnosis of new variant Creutzfeldt-Jakob disease. Ann Neurol 2000, 47:575-582.

7. Ironside JW, Head MW, Bell JE, McCardle L, Will RG: Laboratory diagnosis of variant Creutzfeldt-Jakob disease. Histopathology 2000, 37:1-9.

8. Kovacs GG, Puopolo M, Ladogana A, Pocchiari M, Budka H, van Duijn C, Collins SJ, Boyd A, Giulivi A, Coulthart M, Delasnerie-Laupretre N, Brandel JP, Zerr I, Kretzschmar HA, de Pedro-Cuesta J, Calero-Lara M, Glatzel M, Aguzzi A, Bishop M, Knight R, Belay G, Will R, Mitrova E: Genetic prion disease: the EUROCJD experience. Hum Genet 2005, I I 8:166-174.

9. Wopfner F, Weidenhofer G, Schneider R, von Brunn A, Gilch S, Schwarz TF, Werner T, Schatzl HM: Analysis of $\mathbf{2 7}$ mammalian and 9 avian PrPs reveals high conservation of flexible regions of the prion protein. J Mol Biol 1999, 289:1163-1178.

10. Kovacs GG, Trabattoni G, Hainfellner JA, Ironside JW, Knight RS, Budka $\mathrm{H}$ : Mutations of the prion protein gene phenotypic spectrum. J Neurol 2002, 249: 1567-I582.

II. Horiuchi M, Priola SA, Chabry J, Caughey B: Interactions between heterologous forms of prion protein: binding, inhibition of conversion, and species barriers. Proc Natl Acad Sci USA 2000, 97:5836-584I.

12. Nurmi MH, Bishop M, Strain L, Brett F, McGuigan C, Hutchison M, Farrell M, Tilvis R, Erkkila S, Simell O, Knight R, Haltia M: The normal population distribution of PRNP codon 129 polymorphism. Acta Neurol Scand 2003, 108:374-378.

13. Alperovitch A, Zerr I, Pocchiari M, Mitrova E, de Pedro Cuesta J, Hegyi I, Collins S, Kretzschmar H, van Duijn C, Will RG: Codon I 29 prion protein genotype and sporadic Creutzfeldt-Jakob disease. Lancet 1999, 353:1673-1674.

14. Brandel JP, Preece M, Brown P, Croes E, Laplanche JL, Agid Y, Will R, Alperovitch A: Distribution of codon 129 genotype in human growth hormone-treated CJD patients in France and the UK. Lancet 2003, 362:128-130.

15. Cervenakova L, Goldfarb LG, Garruto R, Lee HS, Gajdusek DC, Brown P: Phenotype-genotype studies in kuru: implications for new variant Creutzfeldt-Jakob disease. Proc Natl Acad Sci USA 1998, 95: I3239-1324I.

16. Goldfarb LG, Petersen RB, Tabaton M, Brown P, LeBlanc AC, Montagna P, Cortelli P, Julien J, Vital C, Pendelbury WW, et al.: Fatal familial insomnia and familial Creutzfeldt-Jakob disease: disease phenotype determined by a DNA polymorphism. Science 1992, 258:806-808.

17. Ward HJ: Surveillance of Creutzfeldt Jakob disease in the United Kingdom. Euro Surveill 2000, 5:90-94.

18. Parchi P, Giese A, Capellari S, Brown P, Schulz-Schaeffer W, Windl O, Zerr I, Budka H, Kopp N, Piccardo P, Poser S, Rojiani A, Streichemberger N, Julien J, Vital C, Ghetti B, Gambetti P, Kretzschmar H: Classification of sporadic Creutzfeldt-Jakob disease based on 
molecular and phenotypic analysis of 300 subjects. Ann Neurol 1999, 46:224-233.

19. Bishop M, Hart P, Aitchison L, Baybutt H, Plinston C, Thomson V, Tuzi N, Head M, Ironside J, Will R, Manson J: Predicting susceptibility and incubation time of human-to-human transmission of vCJD. Lancet Neurol 2006, 5(5):393-398.

20. Llewelyn CA, Hewitt PE, Knight RS, Amar K, Cousens S, Mackenzie J, Will RG: Possible transmission of variant Creutzfeldt-Jakob disease by blood transfusion. Lancet 2004, 363:417-42I.

21. Peden AH, Head MW, Ritchie DL, Bell JE, Ironside JW: Preclinical vCJD after blood transfusion in a PRNP codon 129 heterozygous patient. Lancet 2004, 364:527-529.

22. Ironside JW, Bishop MT, Connolly K, Hegazy D, Lowrie S, Grice ML, Ritchie DL, McCardle L, Hilton DA: Variant Creutzfeldt-Jakob disease: prion protein genotype analysis of positive appendix tissue samples from a retrospective prevalence study. $B M$ J 2006, 332: I I86-II88.

23. Mead S, Mahal SP, Beck J, Campbell T, Farrall M, Fisher E, Collinge J: Sporadic--but not variant--Creutzfeldt-Jakob disease is associated with polymorphisms upstream of PRNP exon I. Am J Hum Genet 200I, 69: I225-I 235.

24. McCormack JE, Baybutt HN, Everington D, Will RG, Ironside JW, Manson JC: PRNP contains both intronic and upstream regulatory regions that may influence susceptibility to Creutzfeldt-Jakob Disease. Gene 2002, 288: I39-I 46.

25. Funke-Kaiser H, Theis S, Behrouzi T, Thomas A, Scheuch K, Zollmann FS, Paterka M, Paul M, Orzechowski HD: Functional characterization of the human prion protein promoter in neuronal and endothelial cells. J Mol Med 200I, 79:529-535.

26. Mahal SP, Asante EA, Antoniou M, Collinge J: Isolation and functional characterisation of the promoter region of the human prion protein gene. Gene 200I, 268: I05-II4.

27. Cernevakova L, Brown P, Piccardo P, Cummings JL, Nagle J, Vinters HV, Kaur P, Ghetti B, Chapman J, Gajdusek C, Goldfarb LG: 24nucleotide deletion in the PRNP gene: analysis of associated phenotypes. In Transmissible Subacute Spongiform Encephalopathies: Prion Diseases. Edited by: Court L, Dodet B. Paris: Elsevier; 1996:433-444.

28. WHO: Human transmissible spongiform encephalopathies. Wkly Epidemiol Rec 1998, 73:36I-365.

29. Mead S, Stumpf MP, Whitfield J, Beck JA, Poulter M, Campbell T, Uphill JB, Goldstein D, Alpers M, Fisher EM, Collinge J: Balancing selection at the prion protein gene consistent with prehistoric kurulike epidemics. Science 2003, 300:640-643.

30. Pocchiari M, Puopolo M, Croes EA, Budka H, Gelpi E, Collins S, Lewis V, Sutcliffe T, Guilivi A, Delasnerie-Laupretre N, Brandel JP, Alperovitch A, Zerr I, Poser S, Kretzschmar HA, Ladogana A, Rietvald I, Mitrova E, Martinez-Martin P, De Pedro-Cuesta J, Glatzel M, Aguzzi A, Cooper S, Mackenzie J, Van Duijn CM, Will RG: Predictors of survival in sporadic Creutzfeldt-Jakob disease and other human transmissible spongiform encephalopathies. Brain 2004, 1 27:2348-2359.

31. Piccardo P, Dlouhy SR, Lievens PM, Young K, Bird TD, Nochlin D, Dickson DW, Vinters HV, Zimmerman TR, Mackenzie IR, Kish SJ, Ang LC, De Carli C, Pocchiari M, Brown P, Gibbs CJ Jr, Gajdusek DC, Bugiani O, Ironside J, Tagliavini F, Ghetti B: Phenotypic variability of Gerstmann-Straussler-Scheinker disease is associated with prion protein heterogeneity. J Neuropathol Exp Neurol 1998 , 57:979-988.

32. Shibuya S, Higuchi J, Shin RW, Tateishi J, Kitamoto T: Codon 219 Lys allele of PRNP is not found in sporadic Creutzfeldt-Jakob disease. Ann Neurol 1998, 43:826-828.

33. Jeong BH, Lee KH, Kim NH, Jin JK, Kim Jl, Carp RI, Kim YS: Association of sporadic Creutzfeldt-Jakob disease with homozygous genotypes at PRNP codons I29 and 219 in the Korean population. Neurogenetics 2005, 6:229-232.

34. Furukawa $\mathrm{H}$, Kitamoto $\mathrm{T}$, Tanaka $\mathrm{Y}$, Tateishi J: New variant prion protein in a Japanese family with Gerstmann-Straussler syndrome. Brain Res Mol Brain Res 1995, 30:385-388.

35. Hizume M, Kobayashi A, Teruya K, Ohashi H, Ironside JW, Mohri S, Kitamoto T: Human Prion Protein (PrP) 219 K Is Converted to PrPSc but Shows Heterozygous Inhibition in Variant Creutzfeldt-Jakob Disease Infection. J Biol Chem 2009, 284:3603-3609.
36. Palmer MS, Mahal SP, Campbell TA, Hill AF, Sidle KC, Laplanche JL, Collinge J: Deletions in the prion protein gene are not associated with CJD. Hum Mol Genet 1993, 2:54I-544.

37. Laplanche JL, Chatelain J, Launay JM, Gazengel C, Vidaud M: Deletion in prion protein gene in a Moroccan family. Nucleic Acids Res 1990, 18:6745.

38. Capellari S, Parchi P, Wolff BD, Campbell J, Atkinson R, Posey DM, Petersen RB, Gambetti P: Creutzfeldt-Jakob disease associated with a deletion of two repeats in the prion protein gene. Neurology 2002, 59:1628-1630.

39. Korth C, Kaneko K, Groth D, Heye N, Telling G, Mastrianni J, Parchi P, Gambetti P, Will R, Ironside J, Heinrich C, Tremblay P, DeArmond SJ, Prusiner SB: Abbreviated incubation times for human prions in mice expressing a chimeric mouse-human prion protein transgene. Proc Natl Acad Sci USA 2003, 100:4784-4789.

\section{Pre-publication history}

The pre-publication history for this paper can be accessed here:

http://www.biomedcentral.com/1471-2350/10/146/pre pub

Publish with Bio Med Central and every scientist can read your work free of charge

"BioMed Central will be the most significant development for disseminating the results of biomedical research in our lifetime. "

Sir Paul Nurse, Cancer Research UK

Your research papers will be:

- available free of charge to the entire biomedical community

- peer reviewed and published immediately upon acceptance

- cited in PubMed and archived on PubMed Central

- yours - you keep the copyright 